\title{
The Effect of Literary vs. Non-literary Texts through Critical Reading Approach on the Reading Comprehension Development of Iranian Intermediate EFL Learners
}

\author{
Maryam Shokrolahi \\ English Department, Islamic Azad University Damavand, Iran
}

\begin{abstract}
The present study aimed at investigating the effect of literary texts vs. non-literary texts through critical reading approach on the reading comprehension development of Iranian Intermediate EFL learners. To achieve this goal, the Preliminary English Test (PET) was employed to determine the homogeneity of the participants regarding their proficiency in English. A group of sixty students with scores one standard deviation above and one standard deviation below the mean was selected as the participants of this study who were female learners and their language proficiency level was intermediate. In both groups the critical strategies are Answering Questions, Previewing, Making Predications, Reading between Lines, Analyzing, and Pair Discussion. The difference was that the subjects in the experimental group worked on short stories as literary texts through critical reading approach but the control group worked on journal articles as nonliterary texts through critical reading approach. To determine whether there was any significant difference between the performance of experimental and control group ascribed to treatment, a reading comprehension test as post test was administered. After the data were processed, the results showed that there was a statistically significant difference between the mean scores of the experimental and control groups. Thus, the null-hypothesis, saying literary vs. non-literary texts through critical reading approach has no significant effect on the reading comprehension development of Iranian intermediate EFL learners, was rejected.
\end{abstract}

Index Terms — critical reading, literary texts, non-literary texts, reading comprehension

\section{INTRODUCTION}

Due to the paramount importance of reading in our daily life in first language, and the role it plays in education as well as in communication, many second or foreign language learners have regarded reading as the most important skills. (Grabe, 2002). The search for a model or process which could suitably account for more effective and efficient reading, comprehension, and appreciation of a reading text for EFL learners has been a controversial and challenging concern among many EFL theorists and researchers as well as practitioners (Carrell, 1988; Smith1982). Researchers put emphasis on the role of critical reading in ELT. For example, Spolsky (1989) argues a case for teaching 'resisting reading' with reference to the use of literary texts in high schools. She suggests one of the purposes of using literary texts is to widen students' horizons, and to introduce students to unfamiliar cultural values. Clark (1993) discussed the problem her overseas students face when studying international relations through the medium of English at a UK university, where their textbooks express largely western viewpoints. They need to be able to recognize the ideology of a text and decide whether they will be submissive or resistant to it. This means a careful analysis of the ways in which language the writer makes choices. Those who advocate the development of critical reading skill as part of the reading curriculum argue that the ability to read critically depends on an awareness of how elements of language can be manipulated by writers, and then language learners need to build this awareness. Critical reading pedagogy requires scrutiny of the language in order to see what the writer means by the text.

Researchers assert that for students who are growing up in world saturated with media and messages, they need to experience a critical pedagogy for analyzing or evaluating these messages (Hobbs, 1988). In addition to choosing, the right material for EFL/ESL classes is an important concern for most language teachers. They often attempt to find texts which are readable, i.e. texts with lexical and structural difficulty that will challenge the students without overwhelming them." (Brown, 2001, p.314). Some teachers use literary texts as basis for critical reading while other teacher use nonliterary texts namely, newspaper articles with different political learning. However, selecting texts for critical reading is a difficult procedure. Teaching critical reading is regarded as particularly important when learners are more vulnerable, for example, school children reading literature who may have insufficient experience to challenge the views of the writer. (Clark, 1993).As an English teacher, the researcher is highly motivated on what kind of text should be selected for reading skill, and what sort of text can have more significant effect on critical reading? Hence, the purpose of this study is how learners develop their critical reading into reading proficiency through literary texts and non- literary texts. 
The result may also help teachers and material designer have better views on using critical reading pedagogy and selecting texts. The question to be answered in this research is as follow:

Q: Does literary vs. non-literary texts through critical reading approach have any significant effect on the reading comprehension development of Iranian intermediate EFL learners?

\section{REVIEW OF THE RELATED LITERATURE}

\section{A. Critical Reading}

In critical reading, the reader is given right to evaluate and to be decisive (Thistlewaite, 1990)and reader plays the role of a filter not to accept passively what is found in the text as seemingly being presented to them as obvious(Wallace,1990). Through critical reading students learn how to have a critical eye all through reading it and not "passively accept what is found in reading texts simply because it is so often presented as obvious" (Wallace, 1990, p.44). Hence, learners through critical reading are given authority and voice to judge about what they read. Learners learn how not to accept whatever are put forward and not take it for granted. Teachers, also, teach learners how to reasonably critique and make inferences about what they read and defend their ideas critically and logically (Edelsky, 1999). Paul \& Elder (2004) believe that critical readers recognize that they have been wrong in the past and may be worried now. They recognize what they would like to believe while at the same time realizing that they may be prejudiced by that very desire. Moreover, critical readers read all texts with equal sympathy. They read to discover and digest a wide range of points of view, especially points of view that tend to be ignored in the mainstream of culture. To enhance their breath of vision while avoiding ethnocentrism and sociocentrism, critical readers search out dissenting media sources. An analysis of the text should be concerned not only with the way stories are constructed but also with who is and who is not allowed to speak (Herman \& Chomsky, 1998).

\section{B. Pros and Cons in Using Literary Texts}

There have been growing interest in literature and its usage in language classroom but some scholars are against literature and literary texts. Here first, the arguments against inclusion of literary texts will be mentioned and then the answers to these arguments will be given. The first reason mentioned for not using literary text is that in the works of the famous writers and specially poets we encounter sentences which are grammatically incorrect so submitting such texts to the students has no use in teaching grammar. The second argument referred to in an essay by Sandra Makey (1991) in "Literature and language teaching", is that literature is useless in meeting students academic and or occupational goods. The third reason for not using literary texts is that "literature often reflects a particular cultural perspective "so it may be quite difficult for students. (Makey, 1991 p.68). The fourth and the last argument, Widdowson in 1978 said that literature has potentially disruptive influence in well-ordered world of controlled language course.

In answer to the first argument, Widdowson (1978) has answered this criticism and says that everybody has two levels of linguistics knowledge, one is "usage" (the knowledge of linguistic rules) and the other is "use" (the knowing how to use these rules).Literature has traditionally been used to teach language "usage" now it is used for language "use". In other words , a close textual analysis of particular extracts from a novel might help to alert students not only to how particular meanings are conveyed by playing with the conventions, but also the certain overall generalizable features of language in this case the nature of collocation. The second criticism is in reference to the uselessness of literature in academic/ occupational needs. Answering this question, Makey (1991) says literature can foster an overall increase in reading proficiency, so it will contribute to these goals. In fact, the main contribution of literary texts, to language learning is in the field of reading. The third reason mentioned for not using literature in classroom is related to the cultural aspect of language. In fact, literature promotes a greater tolerance for cultural differences and the second benefit of struggling with the potential cultural problem of literature is that it promotes students' curiosity. (Makey, 1991). We acknowledge that there are cultural differences but by selecting these literary texts in which cultural characteristics. We can make students familiar with their culture and make the learning environment more interesting. The last argument, literature has a" disruptive influence" in language course. Widdowson said that in fiction and drama, events reveal something of significance which we have recognized as a kind of everyday life. But the pedagogy presentation of language does not exploit the possibilities of creativity that are opened up by dissociation from context, and creativity is a crucial concept in language learning.

\section{MethodOLOGY}

\section{A. Participants}

The participants of this study were 60 intermediate EEL Iranian learners who randomly were divided into the experimental and control groups. All the participants were female and their ages ranged from 14 to 18 . They studied at the intermediate level.

\section{B. Instrumentations}

Five types of instruments were used in this study; Preliminary English Test (PET), Critical reading strategies, Graphic and Semantic Organizers, Material, and Reading comprehension test. First a sample of Preliminary English 
Test (PET) was employed to specify the homogeneity of the participants regarding students' proficiency in English. Second, critical reading strategies; answer questions, Previewing, Making Predications, Reading between Lines, Analyzing, and Pair Discussion were selected. The third, researcher used some graphic organizers and charts not only to help students to improve their comprehension of the texts but also to record what happens in the classrooms through the treatment. The fourth instrument, six short stories as literary texts and six journal articles as non-literary texts were selected. And in this study, the readability indices of 6 reading passages of literary texts and 6 reading passages of nonliterary texts were calculated through Flesch Readability Formula. And the last instrument, Reading Comprehension Test contained five Reading comprehension passages followed by 30 multiple-choice questions used as pretest and post-test in order to measure the dependent variable.

\section{Procedures}

At the first step participants consisted of 90 students. They were female students who finished the Interchange volume three. Then a sample of Preliminary English Test (PET) was employed to assign the homogeneity of the participants as far as their proficiency in English was considered. After the data were processed, out of 90 students, 60 with scores falling between one standard deviation above and one standard deviation below the mean were selected as the participants of this study. Then, the participants were randomly divided into two groups as the experimental and control groups. Afterward, participants in both groups took the pretest of the standardized reading comprehension test which was piloted by the researcher, in order to be sure that there is no significant difference among the members of experimental and control groups before the treatment. In this way, any change in the performance of the experimental group and control group after the treatment can be, most probably, ascribed to the treatment given on the reading performance. After the data were processed, the scores of the pretest were statistically processed through t-test. In this study, the participants were randomly divided into two groups as the experimental and control groups that the former worked on literary texts through critical reading approach, and the latter worked on non-literary texts through the same approach. The critical reading strategies which were selected for the study, namely Answering Questions, Previewing, Making Predications, Reading between Lines, Analyzing, and Pair Discussion.

In this research, the researcher's purpose was to stimulate the learners' creative critical reading through literary texts and non-literary texts. For this purpose ten sessions of instruction were considered, during which, six short stories as literary texts were taught to the experimental group and six journal articles as non-literary texts to the control group. Finally, at the end of the term when ten sessions of instruction were ended, a reading comprehension -the pretest with different order- was given to the participants of both groups as post-test to statistically determine whether there is any significant improvement in the reading comprehension ability of the participants in the experimental and control groups. After the data were processed, the means of the two groups was computed and compared by running t-test.

\section{RESULTS AND DISCUSSION}

An independent t-test was run to compare the mean scores of the experimental and control groups on the PET to show that the two groups were homogeneous in terms of their general language proficiency prior to the administration of the treatment. The t-observed value was .29. This amount of $\mathrm{t}$-value at 58 degrees of freedom was lower than the critical value of 2 .

TABLE1.

INDEPENDENT T-TEST OF PRETEST

\begin{tabular}{|c|c|c|c|c|c|c|c|c|c|c|}
\hline \multicolumn{11}{|c|}{ Independent Samples Test } \\
\hline & & \multicolumn{2}{|c|}{$\begin{array}{l}\text { Levene's Test for } \\
\text { Equality of } \\
\text { Variances }\end{array}$} & \multicolumn{7}{|c|}{ t-test for Equality of Means } \\
\hline & & \multirow[t]{2}{*}{$\mathrm{F}$} & \multirow[t]{2}{*}{ Sig. } & \multirow[t]{2}{*}{$\mathrm{T}$} & \multirow[t]{2}{*}{$\mathrm{df}$} & \multirow[t]{2}{*}{$\begin{array}{l}\text { Sig. (2- } \\
\text { tailed) }\end{array}$} & \multirow[t]{2}{*}{$\begin{array}{l}\text { Mean } \\
\text { Difference }\end{array}$} & \multirow[t]{2}{*}{$\begin{array}{l}\text { Std. Error } \\
\text { Difference }\end{array}$} & \multicolumn{2}{|c|}{$\begin{array}{l}\text { 95\% Confidence Interva } \\
\text { of the Difference }\end{array}$} \\
\hline & & & & & & & & & Lower & Upper \\
\hline \multirow[t]{2}{*}{ PET } & $\begin{array}{l}\text { Equal variances } \\
\text { assumed }\end{array}$ & .014 & .906 & .295 & 58 & .769 & .63333 & 2.14456 & -3.65946 & 4.92613 \\
\hline & $\begin{array}{l}\text { Equal variances } \\
\text { not assumed }\end{array}$ & & & .295 & 57.993 & .769 & .63333 & 2.14456 & -3.65947 & 4.92614 \\
\hline
\end{tabular}

As displayed in Table, the mean scores for the experimental and control groups on the PET test were 46.93 and 47.56 respectively. Based on these results it could be concluded that there was not any statistically significant difference between the mean scores of the experimental and control groups on the PET test. So, the two groups were homogeneous in terms of their general language proficiency prior to the administration of the treatment. 
TABLE2.

DESCRIPTIVE STATISTICS PET TEST

\begin{tabular}{|c|c|c|c|c|c|}
\hline \multicolumn{6}{|c|}{ Group Statistics } \\
\hline & Group & $\mathrm{N}$ & Mean & Std. Deviation & Std. Error Mean \\
\hline \multirow{2}{*}{ PET } & Control & 30 & 47.5667 & 8.35292 & 1.52503 \\
\hline & Experimental & 30 & 46.9333 & 8.25847 & 1.50778 \\
\hline
\end{tabular}

An independent t-test was run to compare the mean scores of the experimental and control groups on the pretest of reading in order to show that the two groups were homogeneous in terms of their reading ability prior to the administration of the treatment. The t-observed value was .24 . This amount of t-value at 58 degrees of freedom was lower than the critical value of 2 .

TABLE3.

INDEPENDENT T-TEST OF PRETEST

\begin{tabular}{|l|l|l|l|l|l|l|l|l|l|l|}
\hline \multicolumn{2}{|l|}{ Independent Samples Test } \\
\hline
\end{tabular}

As displayed in Table, the mean scores for the experimental and control groups on the pre-test of reading were 21.30 and 21.46 respectively. The t-observed value was .24 . This amount of t-value at 58 degrees of freedom was lower than the critical value of 2 .

TABLE4.

DESCRIPTIVE STATISTICS PRETEST

\begin{tabular}{|l|l|l|l|l|l|}
\hline Group Statistics & \multicolumn{5}{|l|}{} \\
\hline & Group & $\mathrm{N}$ & Mean & Std. Deviation & Std. Error Mean \\
\hline PRETEST & Control & 30 & 21.4667 & 2.60944 & .47642 \\
\cline { 2 - 7 } & Experimental & 30 & 21.3000 & 2.60172 & .47501 \\
\hline
\end{tabular}

An independent t-test was run to compare the mean scores of the experimental and control groups on the post-test of reading in order to probe the effect of literary vs. non-literary texts through critical reading approach on the reading comprehension development of Iranian intermediate EFL learners.

TABLE5

INDEPENDENT T-TEST OF POST-TEST

\begin{tabular}{|l|l|l|l|l|l|l|l|l|l|}
\hline \multicolumn{2}{|l|}{ Independent Samples Test } \\
\hline
\end{tabular}

The t-observed value was 3.95. This amount of t-value at 58 degrees of freedom was greater than the critical value of 2.According to the data, the mean scores for the experimental and control groups were 26.93 and 25.40 respectively.

TABLE6.

DESCRIPTIVE STATISTICS POST-TEST

\begin{tabular}{|l|l|l|l|l|l|}
\hline Group Statistics & Group & N & Mean & Std. Deviation & Std. Error Mean \\
\hline \multirow{2}{*}{ POST-TEST } & Experimental & 30 & 26.9333 & 1.38796 & .25341 \\
\cline { 2 - 7 } & Control & 30 & 25.4000 & 1.61031 & .29400 \\
\hline
\end{tabular}


Based on these results it could be concluded that there was a statistically significant difference between the mean scores of the experimental and control groups on the post-test of reading.

\section{CONCLUSION}

In this study, the researcher tried to show the effect of literary vs. non-literary texts through critical reading approach on the reading comprehension development of Iranian intermediate EFL learners. The researcher administered a PET test to determine the homogeneity of sample. The sample was randomly assigned to 30 subjects in control group and 30 subjects in experimental group. In order to measure their initial reading comprehension, all subjects in both groups took a pretest of reading comprehension. The test was piloted with the same level students to determine its readability and validity. After conducting the pretest, the data were processed and in the following a t-test was run which revealed that there was no significant difference in the reading ability of the two groups before the instruction based on their reading comprehension. Then the treatment began. At the end of the treatment period, a post-test of the same reading comprehension test with the same characteristics was administered to clarify the effect of literary vs. non-literary texts through critical reading approach on the reading comprehension development of Iranian intermediate EFL learners. Then the significant difference between the obtained means of the experimental and control group's scores in the posttest was determined through a two-tailed t-test (with the level of significance of 0.05 ). The t-observed value was 3.95 .This amount of $t$-value at 58 degrees of freedom is greater than the critical value of 2 . Based on the results, it could be concluded that there was a statistically significant difference between the mean scores of the experimental and control groups on the post-test of reading. Thus, the null-hypothesis was rejected, and it could be claimed that teaching critical reading techniques through literary texts have a statistically significant effect on the development of EFL learners' reading comprehension. In the other words, the performance of those who had used literary texts as their material was much better than those who had used non-literary text. Therefore, literary texts through critical reading play an important role in the development of reading comprehension of the Iranian intermediate EFL learners.

The results of this study have some hints for English teachers who should pay more attention while teaching reading comprehension. These implications are listed below:

1. The finding of this study showed that Knowledge should be transformed rather than literally transmitted. And teachers must consider that the use of challenging quality reading materials based on learner's interest and needs is really pivotal and also use of challenging quality reading materials such as short stories should be encouraged.

2. As a result, this study showed that teaching reading of literary texts through critical reading approach played an important role in the development of Iranian intermediate EFL learners. Hall (2005) argued that literature represents challenging materials for learners and teachers as a view of language and language learning to investigate, discuss. So, the use of stories as the most comprehensive and promising form of texts should be inseparable from EFL reading (Goodman \&Goodman, 1981).

3. Critical reading is an important topic in modern education. In every course, especially in content subjects, students should be taught to read logically, to analyze, to compare, to question, and to evaluate the content. The result of this study showed that critical reading strategies such as Answering Questions, Previewing, Making Predication, Reading between Lines, Analyzing, and Pair Discussion can be used to pave the way for critical reading and reading comprehension.

4. The determining role of literary texts in fostering reading comprehension through critical reading approach has been proved in this study. So the result of this study could have significant implication for syllabus designers, material developers, and those preparing reading textbooks. They can achieve a better result by careful selection of appropriate texts especially by including literary texts in reading text books.

\section{REFERENCES}

[1] Birckbichler, D.W., \& J.A Muyskens. (1980) A Personalized approach to the Teaching of literature at Elementary and Intermediate Levels of Instruction. Foreign Language Annals, 13, 23-27.

[2] Brown, D. H. (2001). Teaching by principles: An interactive approach to language pedagogy. New York: Longman.

[3] Clark, R. (1993). Developing practices of resistance: critical reading for students of politics in D. Graddol, L. Thompson, \& M. Byram (eds.). Language and culture. Clevedon, Avon: BAAL/Multilingual Matters. 113-22.

[4] Carrell, P.L. (1988). Interactive text processing: Implications for ESL/second language reading classrooms .In P. L. Carrell, J. Devine, \& D. E. Eskey (Eds.), Interactive Approaches to Second Language Reading. (.239-259).Cambridge: Cambridge University Press.

[5] Carter, R. (2007). Literature and language teaching 1986-2006: A review. International Journal of Applied Linguistics, 17(1), 3-13.

[6] Clark, R. (1993). Developing practices of resistance: critical reading for students of politics in D. Graddol, L. Thompson, and M. Byram (eds.), Language and culture. Clevedon, Avon: BAAL/Multilingual Matters, 113-22.

[7] Edelsky, C. (1999). Making Justice Our Project: Teachers Working Towards Critical Language Practice. Urbana, Illinois: NCTE.

[8] Friere, P. (1991). The importance of the act of reading. In C. Mitchell (ED.). Rewriting Literacy: Culture and the Discourse of the Other .London: The Flamer Press, 139-145. 
[9] Ghosn, I.K. (1994). Whole Language EFL with children's Literature. The way it worked in one kindergarten class .(ERIC NO.398 733), 1-16

[10] Goodman, K. S., \& Goodman, Y. (1981). A Whole Language Comprehension Centered View of Reading Development: A Position paper (Occasional Paper No.1). Tucson, AZ: University of Arizona, Program in Language \&Literacy.

[11] Grabe, W. (2002a). Dilemma for the development of second language reading abilities, In J.C. Richards \& W. A. Renandya (Eds.) Methodology in language teaching (pp.276-288). Cambridge: Cambridge University Press.

[12] Kress, G. (1985). Linguistic process in sociocultural practice. Oxford: Oxford University Press.

[13] Herman, E. \& Chomsky, N. (1998). Manufacturing consent: The political economy of the mass media. New York: pantheon

[14] Hobbs, R. (1998).Literacy for the information age. In James flood, Diane Lapp and Shirely Brice Health (Eds.), Handbook of Research on Teaching Literacy through the communicative and visual Arts (.7-14).New York: Macmillan.

[15] Makey,S.(1991).“Literature in ESL classroom” TESOL Quarterly 16.4, 68.

[16] Paran, A. (2008). The role of literature in instructed foreign language learning and teaching: An evidence-based survey. Cambridge University Press 41, 465-496.

[17] Paul, R. \& Elder, L. (2004). How to read a paragraph: The art of close reading. Retrievednovember20, 2009 from http://www.critical thinking.org/resources/articles/-ct-art-close-reading-p3.shtml.

[18] Scott, C. T. (1965). Literature and ESL program. In H.B. Allen (Ed.), Teaching English as a second language: A book of readings (292-299). New York: McGrow Hill.

[19] Smith, F. (1982). Understanding Reading: A Psycholinguistic Analysis of Reading and Learning to Read (3red). New York: Holt, Rinehartb and Winston.

[20] Spolksy, E. (1989).I come to bury Caesar, not to praise him teaching resisting reading. ELT Journal 43.3, 173-9.

[21] Thislewaite, L.L. (1990).Critical reading for at risk students. Journal of Reading, 33.3, 586-592.

[22] Wallace. C. (1990).When a learner attempts to become literate in a second language, what is he or she attempting? TESL TALK.20.1, 29-30.

[23] Wallace, C. (1995). Reading with a suspicious eye: critical reading in the foreign language classroom. In G. Cook \& Seidlhofer (Eds.), Principle and practice in Applied Linguistics (64-73). Oxford: oxford University Press.

[24] Widdowson, H. G. (1978). Teaching language and communication. London: Oxford University Press.

[25] Zarillo, J. (1989). Teachers' interpretation of literature-based reading instruction. The Reading Teacher, 43, $22-28$.

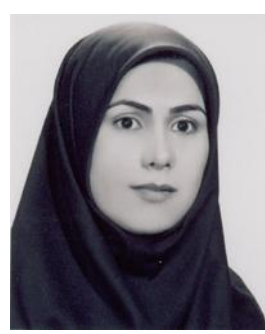

Maryam Shokrolahi is a faculty member of English Language Teaching Department at Damavand Islamic Azad University, Iran. She got her B.A. in English Literature and her M.A. in TEFL from Islamic Azad University. Her areas of interest include SLA, sociolinguistics, cognitive linguistics, discourse analysis, curriculum Planning/evaluation, and language teaching methodology. 